<原 著 $>$

\title{
散発性急性 $\mathrm{A}$ 型肝炎の臨床像
}

$\begin{array}{llllrll}\text { 坂本 } & \text { 裕治 山田剛太郎 } & \text { 西原 } & \text { 隆 } & \text { 水野 } & \text { 元夫 } \\ \text { 系島 } & \text { 達也 } & \text { 平川 } & \text { 弘泰* } & \text { 小林 } & \text { 敏成 } & \text { 有正 修道** } \\ \text { 吉田 } & \text { 智郎*** } & \text { 長島 } & \text { 秀夫* } & & & \end{array}$

\begin{abstract}
要 旨 : 血清中の抗 A 型肝炎ウイルス抗体価の測定 扣よび便中の A 型肝炎ウイルスの検索より急 性 A 型肝炎と診断しえた散発例についてその臨床像をまとめ, 流行性の A 型肝炎, 散発性 B 型お よび非 A 非 B 型急性肝炎と比較検討を扣こなった，A型肝炎と診断できた症例は15例（男 9 例, 女 6 例）で，外国よりの感染を疑われた 2 例を除く症例は，いずれる 1 月より 4 月の冬から春に 散発性に発症し，また，家族内二次感染が推測された 3 例を除いては，いずれもその感染経路は 不明であった。前駆症状は，発熱等の多彩な症状を示す例が多く，病初期の末梢血液像では，異 型リンパ球は 6 例に出現し，ちち1例は15\%と多かった。肝機能検査では，病初期より TTT, IgM の高値を認める症例が多く, 特に TTT $10 \mathrm{u}$ 以上, IgM $500 \mathrm{mg} / \mathrm{d} l$ 以上の高値を示したの はA 型肝炎だけであった。回復期の肝組織像は， B 型急性肝炎の回復期の像と鑑別は困難であっ た. 経過は良好で慢性化した例はなかった。
\end{abstract}

索引用語： $\mathrm{A}$ 型肝炎（散発性急性） $\mathrm{A}$ 型肝炎ウイルス 抗 $\mathrm{A}$ 型肝炎ウイルス抗体

\section{1. 緒 言}

最近本邦でる抗A型肝炎ウイルス抗体 (HA 抗体) の 測定が可能となり，各地で $\mathrm{A}$ 型肝炎の集団発生 ${ }^{1,2,8,4)}$ が 報告されてきているが，HA 抗体の測定が一般化されて いない現状では，散発例の報告は少ない。われわれは， 今回 HA 抗体を測定し, 散発性 A 型肝炎之診断した症 例の臨床像厄ついて詳細飞観察し，従来の流行例との比 較，また同時に非輸血後の散発性急性B 型括よび，散発 性急性非 A 非 B 型肝炎との比較検討を括こなった。

\section{2. 対象ならびに方法}

対象は，A型肝炎と訩断できた15例で，このらち 3 例 は，家族内感染を思わせた親子例で，二次感染が疑われ た. 対照群は，腹腔鏡下肝生検にて急性肝炎之診断され た B 型肝炎 9 例と，非 $\mathrm{A}$ 非 B 型肝炎 2 例で，いずれも非 輸血後の散発性肝炎を対象とした。

方法は，A型肝炎の䛦断には，Abbott 社より提供され た HAVAB キットによる radioimmunoassay, ${ }^{5,6)}$ (RIA

* 岡山大学第 1 内科

** 川崎医科大学内科

*** 日本鋼管福山病院内科
法）と免疫粘着血球凝集反応 ${ }^{2}$ (IAHA 法) で HA 抗 体を測定し，また 4 例に打いては，免疫電子顕微鏡法) (IEM 法) 飞て凟便中のA 型肝炎ウイルス (HAV) を 検索した. RIA 法による HA 抗体価は，矢野らの方 法年に準して，M-index を算出した。疫学については, 発症季節，潜伏期，男女差，年秢差について，また，臨 床像については, 自覚症状, 他覚症状, 血液検査, 組織 所見について検討を加えた，血液検查は，一般血液検 查，総ビリルビン值 (T. Bil. mg/dl), s-GOT, s-GPT

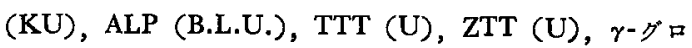
ブリン $(\mathrm{g} / \mathrm{d} l)$, 免疫グロブリン定量（免疫拡散法 $\mathrm{mg} / \mathrm{d} l$; Hylland-イムノプレート) を比較 した。組織標本は, H.E. 染色，Azan 染色，PAS 染色， d-PAS 染色，渡銀 染色で検討した. また，一部では, HA 抗体 (N.I.H.の R.H. Purcell 博士より提供をらけた)の Fab’ そペルオ キシダーゼて標識した conjugate を利用して，醉素抗体

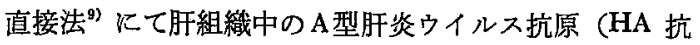
原）観察した。

1)ウイルス学的診断

\section{3. 成 績}

RIA 法, IAHA 法, IEM 法によりA 型肝炎と部断し 
Table 1. Evaluation of anti-HA by radioimmunoassay, immune adherence hemagglutination and immune electron microscopy.

\begin{tabular}{|c|c|c|c|c|c|c|c|}
\hline \multirow[t]{2}{*}{ as } & \multirow[t]{2}{*}{ age } & \multirow[t]{2}{*}{ sex } & \multirow{2}{*}{$\begin{array}{l}\text { HAV } \\
\text { in stool } \\
\text { by IEM }\end{array}$} & \multicolumn{2}{|c|}{$\begin{array}{l}\text { Anti HA by RIA } \\
M \text {-index }\end{array}$} & \multicolumn{2}{|c|}{ Anti HA by IAHA } \\
\hline & & & & \begin{tabular}{|l|l} 
onset $(\cdot)$ \\
\end{tabular} & ) |recovered ( & onset $(\cdot)$ & Jecovered $(\cdot)$ \\
\hline 1 & 8 & male & & $1.68(10)$ & & & \\
\hline 2 & 24 & male & $(-)$ & & & $<8 \quad(\theta)$ & $32(34)$ \\
\hline 3 & 25 & female & & 145 & 2.24 & $<8$ (10) & $512(64)$ \\
\hline 4 & 26 & female & 5 & 123 & $\longdiv { 0 7 6 }$ & $<8$ (14) & $1024(53)$ \\
\hline 5 & 27 & male & & 140 & 1.10 & $<8$ (14) & $<8(53)$ \\
\hline 6 & 28 & male & $(-)$ & 1.47 & 1.01 & $<8$ (10) & $512(72)$ \\
\hline 7 & 29 & male & & 2.12 & 1.34 & $<8 \quad(7)$ & $32(50)$ \\
\hline 8 & 30 & female & $(-)$ & 1.55 & 1.15 & $<8 \quad(15)$ & $256(49)$ \\
\hline 9 & 31 & male & 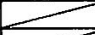 & 184 & 0.86 & $<8$ (12) & $256(50)$ \\
\hline 10 & 31 & male & & $\begin{array}{ll}1.51 & (10) \\
\end{array}$ & $1.14(1$ & $\leq 8(18)$ & $2048(113$ \\
\hline 11 & 34 & male & & $1.36 \quad(12)$ & 1.12 & $<8(12)$ & $512(160$ \\
\hline 12 & 36 & female & & & 1.21 & 12) & \\
\hline 13 & 50 & female & & $1.77(15)$ & 6) 1.22 & $<8(15)$ & $4096(84$ \\
\hline 14 & 51 & male & & $1466(14)$ & 1.07 & $<8$ (14) & $64(89$ \\
\hline 15 & 58 & female & $(+)$ & 1.68 & 1.38 & & \\
\hline
\end{tabular}

(*the day since the onset of subjective symptoms) The secondary infection in a family was suspected in three cases.

case 15 from her son (case 10)

case 1 from his father (case 11)

case 3 from her mother (case 13)

た症例を Table 1 に示す, 症例 5 では, RIA 法で, 病 初期に M-index が1.40と有意に上昇し，症状発現後53 日には1.10と下降がみられたにもかかわらず, IAHA 法 では, 病初期, 回復期（症状発現後53日）とも8倍以下 であったまたＩEM 法により検索した 4 例では，自 賞症状発現後 6 日目，7日目，11日目，14日目の䨋便を 材料に各々検索したが，6日目に䆏便を採取できた症例 15の 1 例に括いてのみ HAV を観察した (Fig. 1-a, b).

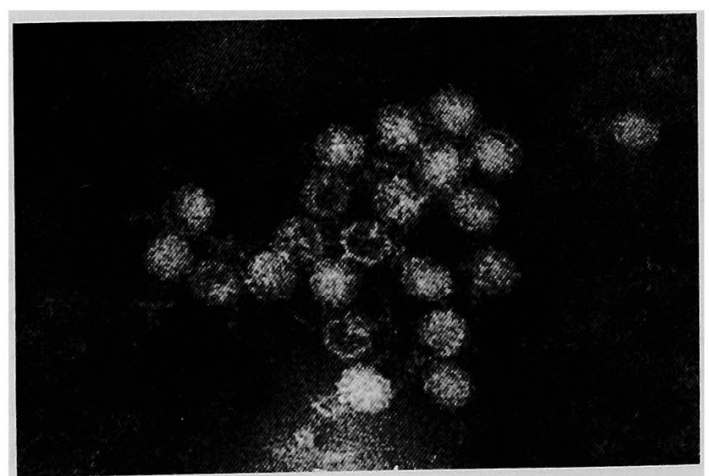

Fig. 1-a Hepatitis A virus particles about $27 \mathrm{~nm}$ in diameter, in stool were found by immune electron microscopy. Full and empty particles were observed. Stained with $3 \%$ phosphotungustic acid. $\times 200,000$

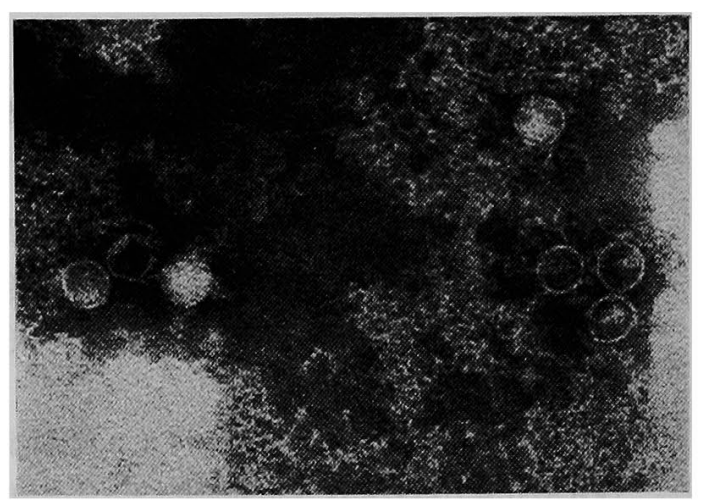

Fig. 1-b Purified HAV by sucrose gradient ultracentrifugation method. Stained with $3 \%$ phosphotungustic acid. $\times 200,000$

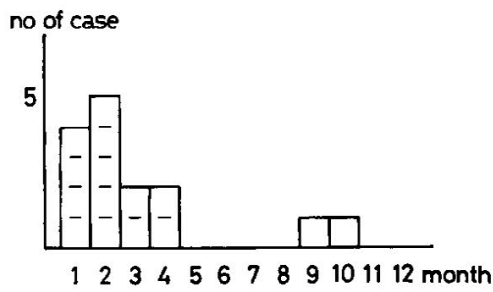

Fig. 2 Monthly occurence of hepatitis A. Almost cases developed between January and April. Two cases in September and October were taken after foreign travel.

しかし，この症例でも10日目の粪便からは，HAV は証 明できなかった。

2) 疫学

今回検討した15例について，その発症月日をみてみる と, 東南アジア旅行後発症し, その母親に二次感染をき たした親子例 2 例を除き，1月中旬より 4 月下旬に発症 している (Fig. 2)。このうち，3組は，家族内感染を思 わせる親子例で，それらの潜伏期は，23日，37日，39日 であり，二次感染が疑われた，東南アジア旅行後発症し た 1 例と，二次感染が疑われた 3 例を除くと，その感染 経路については不明であった，年跲別にみると，8歳 1 例，20歳台 6 例，30歳台 5 例，40歳台 0 例，50歳台 3 例 であり，亏ち男性 9 例，女性 6 例であった.

\section{3）臨床像}

a) 自他覚所見

3 者間の初発症状の比較を Table 2 亿示す。A型肝炎 では，多彩な症状を呈し，特に発熱をきたしたものが， B 型肝炎，非 A 非B 型肝炎に比 L，93.3\%と多かった. 
Table 2. Comparison of initial symptoms among type $A$, type $B$ and non-A non-B hepatitis.

\begin{tabular}{|l|c|c|c|}
\hline & Type A & Type B & nonAnonB \\
\hline fever & $14(93.3 \%)$ & $1(11.1 \%)$ & 0 \\
general fatigue & $12(80.0 \%)$ & $6(66.7 \%)$ & 0 \\
anorexia & $12(80.0 \%)$ & $4(44.4 \%)$ & 0 \\
nausea & $10(66.7 \%)$ & $2(22.2 \%)$ & 1 \\
vomiting & $7(46.7 \%)$ & $1(11.1 \%)$ & 1 \\
headache & $5(33.3 \%)$ & 0 & 2 \\
myalgia & $3(20.0 \%)$ & 0 & 1 \\
arthralgia & $2(13.0 \%)$ & 0 & 1 \\
epigastralgia & $1(6.7 \%)$ & $1(11.1 \%)$ & 1 \\
eruption & $1(6.7 \%)$ & $1(11.1 \%)$ & 0 \\
\hline Total & 15 & 9 & 2 \\
\hline
\end{tabular}

他覚所見では肝腫，脾濁音の拡大をみるものが多かった が特異的なるのではなかった。

b) 血液検查

初診時は，自覚症状発現後 3 日〜18日であるが，初診 時の血液像をみると白血球数は，4,000以下が15例中 2 例, 4,000 5,000が15例中 6 例にみられた。 また，リン パ球50\%以上のリンパ球増多症は，15例中 3 例にみられ た. 異型リンパ球は，15例中 6 例にみられた.この細胞 は，大型の細胞で，大きさは16〜24 $\mu$ 前後で，核も大き く，多形であった．核が棈円形，腎形，不整形を呈し， 比較的単球に似た Downey I 型に類似した細胞や，核は 類円形で，核は偏在し，形質細胞に似た Downey II 型に 類似した細胞が認められた。その出現頻度は1例では15 \%と高い数字を示し，他の 5 例ではいずれる1〜2\%と 低かった. B型肝炎では，白血球数 4,000 以下は 9 例中 2 例, $4,000 \sim 5,000$ が 9 例中 3 例であり，リンパ球が50 $\%$ 以上の症例はなかった。 また， B型肝资 9 例中 2 例に $1 \sim 2 \%$ 異型リンパ球の出現が認められた.

c) 肝機能検查

A 型肝炎の GOT, GPT, T.Bil., ALP, TTT, ZTT, $\gamma$-グロブリンおよび免疫グロブリンの経過中の最高值を B 型肝炎和よび非 A 非B 型肝炎のそれと比較して Fig. 3-a, b に示した. GOT, GPT, T.Bil., ALP, ZTT, $\gamma$-グ ロブリン，IgG，IgA の值には有意差はなかった，TTT は， $\mathbf{A}$ 型肝炎と B 型肝炎の間で，有意差が認められた が， B型肝炎に扎いて TTT が5U〜9U の軽度ない し中等度の上昇を示した症例が 3 例あった。しかし， 型肝炎で TTT が10U 以上を示した症例はないのに比し て，A型肝炎では10U 以上を示した症例を 6 例詔めた。 IgM る，A型肝炎とB型肝炎の間で有意差が認められ

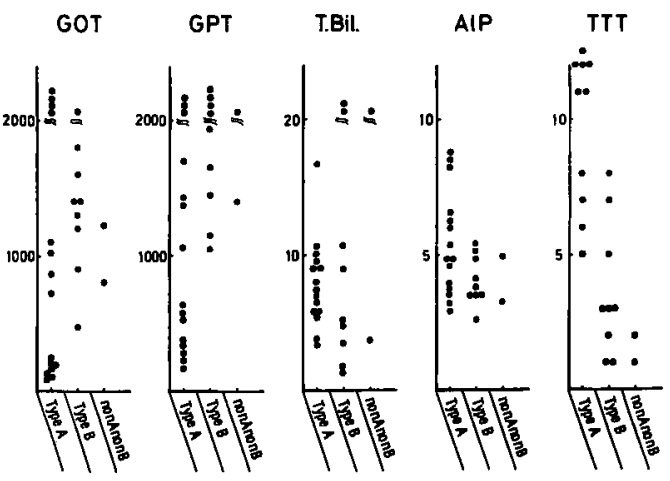

Fig. 3-a Maximum levels of laboratory data (GOT u., GPT u., total bilirubin $\mathrm{mg} / \mathrm{d} l$, alkalin phosphatase B.L.u., thymol turbidity test u.) were compared among type $A$, type $B$ and non- $A$ non-B hepatitis.

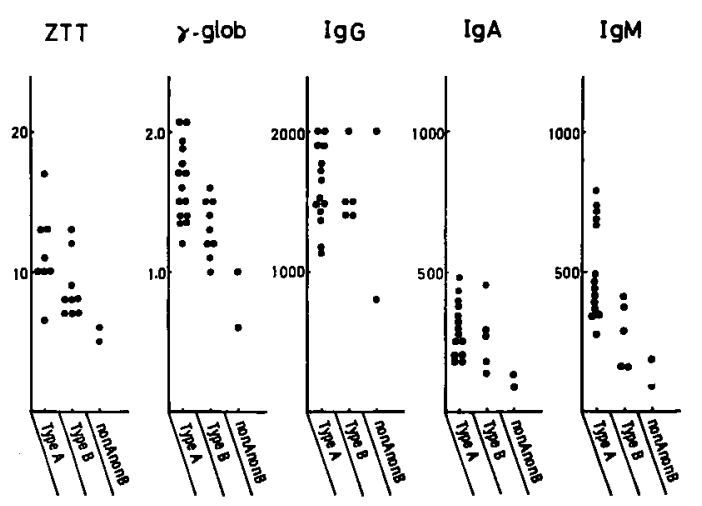

Fig. 3-b Maximum levels of laboratory data (ZTT u., $\gamma$-globulin $\mathrm{g} / \mathrm{d} l, \mathrm{IgG} \mathrm{mg} / \mathrm{d} l, \mathrm{IgA} \mathrm{mg} / \mathrm{d} l, \mathrm{IgM}$ $\mathrm{mg} / \mathrm{d} l$ ) were compared among type A, type B and non- $A$ non- $B$ hepatitis.

た、 B型朋炎においても IgM の上算を示した症例が 3 例あったが， $500 \mathrm{mg} / \mathrm{d} l$ 以上を示した症例はなく， $\mathrm{A}$ 型 肝炎では， 5 例が $\operatorname{IgM} 500 \mathrm{mg} / \mathrm{d} l$ 以上であった. 血清 トランスアミナーゼの正常化に要した平均日数は， $\mathrm{A}$ 型 肝炎では51.4日，B型肝炎では66.4日，非 A 非 B型肝炎 では62.0日であった。

d) 肝組䄳所見

A 型肝资のらち 3 例に执いて，それぞれ，自覚症状出 現後52日，54日，56日に腹腔鏡下で肝生検が扢こなわ れ，その組織像について検討した。その組織像を Fig. 4 に示す．実質部では，小葉中心部の肝細胞の膨化，脂肪 滴の沈着が認められ，小壊死巣，後結節も散見された。 


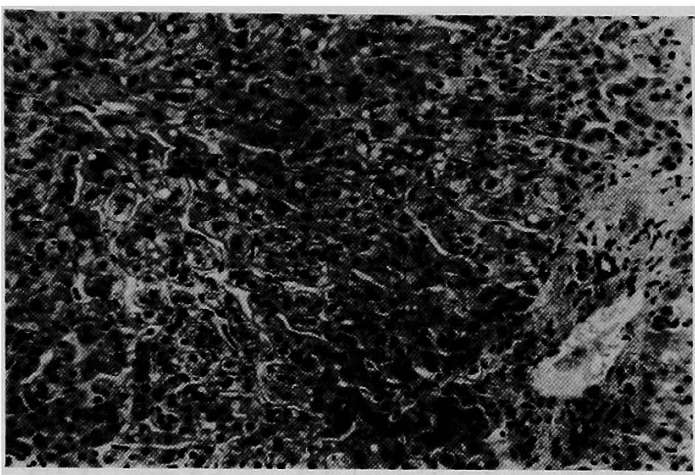

Fig. 4 Light microscopic picture of the liver biopsy specimen obtained from a patient with hepatitis A. H.E. stain $\times 300$

Kupffer 細胞の腫大，貪食および集合像も認められた。 また，門脈域の軽度の拡大，ならびに少数の細胞の浸潤 も認められ，急性肝炎の回復期の像と考光られた。

また，52日目に肝生検を就なった1例に和いて，酵 素抗体直接法で HA 抗原を観察したが，陰性であった。

\section{4. 考 案}

A型肝炎の診断には, 従来 IEM 法, IAHA 法また最 近では RIA 法 ${ }^{10,11\}}$ が開発されてきた. しかしながら, HA 抗原としての HAV の供給が限られているため，そ の診断は，一般に普及していないし，流行例の報告は各 地でなされてきているが，散発例の報告屾，数少ない。 われわれは，RIA 法を中心にA 型肝炎の診断を試み，ま た同時に，一部の症例では IEM 法於よび IAHA 法も 併用した. HAVAB キットKよる診断では，いずれも急 性期の M-index は，1.2以上を示し，発症早期化診断が 可能と考えられた。 また，一部の症例では，IEM 法で

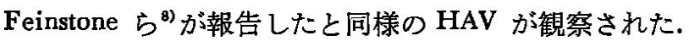
しかし，従来いわれている上うに，発病初期の瓷便にし か証明されず，われわれの検討でる，自覚症状出現後 6 日目の糞便中より HAV を証明したが，7 日目以降の 䔬便中には HAV を証明できなかった。 また，12症例 について, IAHA 法》で HA 抗体価を湘定したが, 症 例 5 を除いて，回復期の血清でいずれるHA 抗体価の 上昇が認められた。症例 5 では，症状出現後14日目の M-index が1.40 と有意の上昇がみられ，から臨床的にも A 型肝炎が疑われたが，症状出現後53日目の血清の HA 抗体価は IAHA 法でなお 8 倍以下と低かった。これ は. 個体の免疫応答が革いためではないかと推測してい るが，今後，経過をみる必要があるるのと思われる.
A 型肝炎の流行季節は，秋から冬といわれている 18) - われわれの散発例の観察では，1月中旬より4月下 旬に発症している症例が多く, むしろ冬から春にかけて みられた，親子例 3 組で潜伏期を検討したが，3〜6週 で，従来の報告と汪汪同様であったＡ型肝炎流行の感 染経路については，欧米では Food borne hepatitis とし ての報告 ${ }^{14,15)}$ が多いが，わが国では，飲料水污染を主と した水系感染が滪われる例が多く報告 ${ }^{16,17,18)}$ されている ようである. 今回の検討では, 海外旅行後発症した 1 例 と，3例の二次感染例の他住，感染経路厄ついては不明 である. 男女比は $3: 2$ で差はなく, 年齢は $8 \sim 58$ 歳で 8 歳 1 例， 20 歳台 6 例， 30 歳台 5 例之従来の報告之同様 に若年者に多い傾向が珰められたが，50歳台にも 3 例観 察された。

自覚症状としては，発熱，全身倦虫，食欲不振，呕気 が高頻度にみられ，特に発熱をきたしたものが多く，症 状が多彩であった．これらは従来の報告とあまり変わり がなく, 他覚所見でも特徴的所見は認められなかった。

急性ウイルス性肝炎において, 末梢血の白血球数は潜 伏期の初めに增加し，後に減少する ${ }^{199}$ といわれている. われわれの検討でも， $\mathrm{A}$ 型肝炎では4,000以下が $13.3 \%$ ， 4,000 5,000が40\%に みられた. B 型肝炎でも 4,000 以

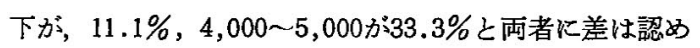
られなかったまた，相対的りンパ兆の増加もみられ る19)といわれているが，われわれの検討では，A型肝炎 において20\%にみられた. 異型リンパ球についても, $\mathrm{A}$ 型肝炎でしばしば出現することが報告4,20)されている が，今回の検討では，15例中 6 例にみられ，その程度は 1 例では15\%と多かったが，他の症例では 1〜2\%と少 なかった。また， B型肝炎においても，9例中 2 例沉異 型リンパ球が出現した. 異型リンバ球の多数の出現は, Epstein Barr ウイルスによる急性肝炎でよく知られてい るが,われわれの経験した急性肝炎様の症状で発症した 伝染性単核球症の一例 ${ }^{21}$ では，異型リンパ球が $11 \%$ と增 加し, 白血球数 14,000, リパ球 $65.5 \%$ と絶対的リンパ 球の增加が観察された。異型リンパ球は, Downey ら により, 形態学的に3つの型にわけられており，また Litwins ら $^{23)}$ は伝染性単核球症に扎いてみられる異常り ンパ球と同様な形態の細胞が，その他の種々なウイルス 性疾患にす出現することを確かめ,この異常リンパ球群 に対し，“virocyte”なる名称を与えて一括することを提 唱した，当教室に扣いても，昭和26年秋頃より岡山県赤 磐郡能山町で起った流行性肝炎83例の血液像を检討し, 
多くの症例で異型りンパ球が出現することを認め，類形

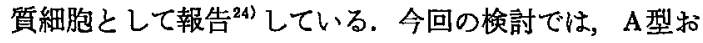
よびB型肝炎の一部の症例活いて，Downey の I 型な

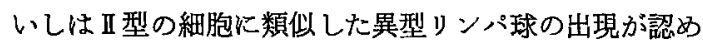
られた，これらの細胞は，伝染性単核球症に括ける異型 リンパ球之形態学的に 鑑別は困難であった。A型肝炎 の一例に怙いて，異型リンパ球が15\%と高率にみられた が，単に時期的な差巽とは考克にくく，host 側の免疫応 答の差異等についての検討も必要であるう。また，伝染 性単核球症でみられる異型リンパ球は，T細胞であるこ とが判明している ${ }^{25,26)}$. 急性肝焱において出現する異型 リンパ球がこれと同一のものかどらか免疫学的検索が 今後必要である.

A型肝炎に捕ける血液生化学検査の特徵として, TTT, IgM の上昇は上く知られている ${ }^{27)}$ ．われわれの検討で も，A型肝炎の全例で TTT，IgM の上昇を認めた，ᄂ かし， B 型肝炎でも少数例ではあるが TTT が高值を示 す例があると報告してきたが ${ }^{28)}$ ，今回の検討でも，B型 肝炎汇批いて，TTT，IgM の上昇を示した例があり， TTT，IgM の上昇の側で，A型肝资と診断することは難 しい. しかし， B型肝炎で TTT が10U 以上，IgM が $500 \mathrm{mg} / \mathrm{d} l$ 以上を示した症例はなく，TTT $10 \mathrm{U}$ 以上， IgM מ $500 \mathrm{mg} / \mathrm{d} l$ 以上の高值を示寸症例は，A型肝炎を 強く疑わせるものと考えられる．他の肝機能検查では， 従来の報告と同様に B 型肝炎との差は少なかった.

また，A型， B 型肝炎の散発例炕沶いては，予後良好 例が多い ${ }^{299}$ とされているが，われわれの症例でも慢性化 した例はなかった，血清トランスアミナーゼの回復期ま での平均日数51.4日は, $\mathrm{Krugman}^{30)}$ の19日，小池ら ${ }^{18)}$ の流行例48日比し長かった. 今回の対象は，殆んどが 成人例で，基山町の流行などでみられたように，成人の 方が正常化が漣れる傾向があるとの報告2ああり，単に 流行による差だけでなく，年齢による差などについても 今後症例をふゃして検討する必要がある.

肝組織像については，チンパンジーの感染実験 ${ }^{31}$ で, 小葉周辺部の炎症所見が，A型肝炎に特改的とされてい るが，人の流行例飞拈ける $\mathrm{A}$ 型肝炎例については谷川 ら゙が詳細比報告している。すなるち，発病初期の特徵 は，感染実験と同様に，聞脈域の円形細胞浸潤が著しい ことで，また，肝細胞の変化は，小葉中心部に比較して 周辺部に著しく，好酸体などの変化をみとめている。 一 般に balloon 細胞の增加は少ないと述へている。 われわ れの検討では, 肝生検の時期か; 発症後 $1 \sim 2$ カ月の間
でなされたが，門脈域の円形細胞浸潤も軽度で，小葉周 辺部の実質にも著変なく，B 型急性肝炎との鑑別は困難 であった.このような所見の差は主として肝生検の時期 的差異によるものと考えられ，回復期の肝生検による組 織学的猃断からA型ないしはB 型肝炎と訩断すること は，きわめて難しいるのと思われた。

\section{5. 結 語}

急性A 型肝炎散発例と診断しえた15症例について，散 発性 B 型肝炎，非 A 非 B 型肝炎とその臨床像について比 较検討を加奌た。

1） A 型肝炎の診断には RIA 法を中心に，一部の症 例では IAHA 法 IEM 法も併用し，A型肝炎と診断 L えた症例は15例で，年龄は 8 歳から58歳で男 9 例，女 6 例であった。

2）外国よりの感染を疑われた 2 例を除く症例はいず れも 1 月より 4 月の冬から春に散発性に 発症した. ま た，3組の家族内二次感染をのぞいてはその感染経路は 不明であった。

3）前駆症状は，B型肝炎补よび非 A 非B 型肝炎に比 して強く，発熱等の多彩な症状を示した。

4）末梢血液像として，白血球数 4,000 以下が $13.3 \%$ ， 4,000〜5,000が40\%にみられたが， B型肝炎との差は認 ぬられなかった。

異型リンパ球は15例中 6 例にみられ，乞の程度は 1 例 では15\%と多かったが，他の症例では1〜2\%と少なか

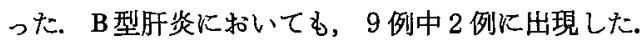

5）肝機能検查では，病初期より TTT，IgM の高值 を認める症例が多く， B 型肝炎でも中等度の上昇を示し た症例はあったが，TTT $10 \mathrm{U}$ 以上，IgM $500 \mathrm{mg} / \mathrm{d} l$ 以 上の高值を示したのはA 型肝炎たけであった。

6）回復期の肝生検組織像は，B型急性肝炎の回復期 の像と鑑別は困難であった.

7）経過は良好で，慢性化した症例はなかった。

本論文の要旨は，第14回日本肝臓学会西部会において 発表した，稿を終るにあたり，IAHA 法により HA 抗 体を測定していたたいた国立予防衛生研究所，州次保雄 博士に深く感謝いたします。またこの研究の一部は厚生 省難治性肝炎研究費によってなされた。

$$
\text { 文 献 }
$$

1）田中智之他：昭和50年和歌山市一地区に発生せ る流行性肝炎，(1)臨床的及び疫学的観察. 肝 蔵, $17: 387,1976$. 
2）谷川久一他：佐賀県基山町に発生した A 型肝炎 の流行について. 第 9 回犬山シンポシウム記 録. 中外医学社, 東京, 1978.

3）奈良秀八州他：ある施設に集団発生したA型朋 炎について. 肝蔵, 19:9，1978.

4) 中野 哲他：中学生に集団発生したA型肝炎の 臨床的検討，第 1 報. $\mathrm{A}$ 型肝炎の診断を中心と して. 肝蔵, $20: 643,1979$.

5) Bradley, D.W. et al.: Serodiagnosis of viral hepatitis $\mathrm{A}$ by a modified competive binding radioimmunoassay for immunoglobulin $\mathbf{M}$ anti-hepatitis A virus. J. Clin. Microbiol., 9 : $120,1979$.

6）矢野右人他：A型急性肝炎の初期血清による診 断. 肝满, $20: 430,1979$.

7) 森次保雄他：免疫粘着血球凝集反応によるA型 肝炎の血清診断. 肝臓, $17: 223,1976$.

8) Feinstone, S.M. et al.: Detection by immune electron microscopy of a viruslike antigen associated with acute illness. Science, 182: 1026, 1973.

9) Yamada, G. \& Nakane, P.K.: Hepatitis B core and surface antigen in liver tissue: Light and electron microscopic localization by the peroxidase-labeled antibody method. Lab. Invest., 36: 649, 1977.

10) Purcell, R.H. et al.: A microtiter solid-phase radioimmunoassay for hepatitis $A$ antigen and antibody. J. Immunol., 116: 2, 1976.

11) Miller, R.H. et al.: Specific immune adherence assay for human hepatitis $\mathrm{A}$ antibody. Application to diagnostic and epidemiologic investigation (38783). Proc. Soc. Exp. Biol. Med., 149 : $254,1975$.

12）鈴木 宏：A型肝炎. 綜合臨牀, $27: 1030,1978$.

13) Maynard, J.E.: Hepatitis A. Am. J. Pathol., 81: 683, 1975.

14) Meyer, J.D. et al.: Food-borne hepatitis A in a general hospital. JAMA, 231 : 1049, 1975.

15) Leger, R.T. et al.: Hepatitis A: Report of a possible etiologic agent. I. Epidemiologic studies. J. Infect. Dis., 131: 163, 1975.

16）高崎 浩：宿題報告, 肝炎の 臨床. 日内会誌,
$61: 461,1972$.

17) 奥田邦雄他 : 福岡県 朝倉郡杷木町に执ける流 行性肝炎の疫学調查. 第 1 報. 日消会誌，67 : $761,1970$.

18）小池通夫他：和歌山市 $\mathrm{N}$ 地区の $\mathrm{A}$ 型朋炎小流行 例について. 小児科臨床, $30: 75,1977$.

19) Zuckerman, A.J.: Human Viral Hepatitis. North-Holland, Amsterdam, 1975.

20）小宅映士他：異型リンパ球による急性肝炎の鑑 別に 関する検討. 第14回日本肝葴学会西部会, 学会報告, 1979 .

21）喜多恵治他：急性肝炎様発症した伝染性単核症 の一例. 日消会誌, $77: 667,1980$.

22) Downey, H. and Makinlay, C.A.: Acute lymphadenosis compared with acute lymphatic leukemia. Arch. Int. Med., 32: 82, 1923.

23) Litwins, J. \& Leibowitz, S.: Abnormal lymphocytes ("Virocytes") in virus diseases other than infectious mononucleosis. Acta Haemat., 5: 223, 1951.

24) 岩原正雄 : 流行性肝炎の血液並びに骨䯣像，第 1 編. 急性期の 血液像. 医学研究, 26: 249, 1956.

25) Sheldon, P.J. et al.: Thymic origin of atypical lymphoid cells in infectious mononucleosis. Lancet, i: 1153, 1973.

26) Pattengale, P.K. et al.: Atypical lymphocytes in acute infectious mononucleosis. Identification by multiple $\mathrm{T}$ and $\mathrm{B}$ lymphocyte markers. New Engl. J. Med., 291 : 1145, 1974.

27) Krugman, S. \& Gogke, D.J.: Viral hepatitis. W.B. Saunders Co. Philadelphia, London, Tronto, 1978.

28）小坂淳夫：オーストラリフ抗原の臨床的意義に 関する今後の問題点. 綜合臨牃, 20:787,1971.

29) 古田精市他: 非 A 非 B 型肝炎. 綜合臨壯, 27 : 1049, 1978.

30) Krugman, S. et al.: Infectious hepatitis, evidence for two distinctive clinical, epidemiological and immunological types of infection. JAMA, 200: 365, 1967.

31) Dienstag, J.L. et al.: Experimental infection of chimpanzee with hepatitis A virus. J. Infect. Dis., 132: 532, 1975. 
Clinical studies on sporadic acute hepatitis A

\author{
Yuzi Sakamoto, Gotaro Yamada, Takashi Nishihara, Motowo Mizuno, \\ Tatsuya Itoshima, Hiroyasu Hirakawa, Hideo Nagashima*, \\ Toshinari Kobayashi, Naomichi Arimasa** and \\ Tomoro YoshidA***
}

The clinical and epidemiological studies of sporadic type A hepatitis were reported. Fifteen cases were diagnosed as hepatitis $A$ by radioimmunoassay (HAVAB), immune adherence hemagglutination and immune electron microscopy. Eleven cases were taken sporadically between January and April, and two patients were infected by secondary spread in the family. Two other patients developed after travel in Southeast Asia. However, sources of the infection were not proved in these sporadic cases. Signs, symptoms and laboratory data of hepatitis A were compared with sporadic hepatitis B and non-A non-B hepatitis. Patients with hepatitis $A$ often had various preicteric symptoms as fever, general fatigue and anorexia. Of laboratory data, both thymol turbidity and immunoglobulin $M$ were elevated in hepatitis A. The histology of liver biopsies obtained from 3 cases of them in the recovery stage showed the convalescent stage of acute hepatitis, but were not significantly different from that of hepatitis $B$.

* The First Department of Internal Medicine, Okayama University Medical School (Okayama)

** Department of Internal Medicine, Kawasaki Medical College (Okayama)

*** Internal Medicine of Nippon Kokan Fukuyama Hospital (Fukuyama) 